\title{
Risk in Real Estate DeVelopment: A Perception of DEVELOPERS IN NIGERIA
}

\author{
Zainab Toyin Jagun* \\ Department of Real Estate, Faculty of Built Environment and Surveying \\ Universiti Teknologi Malaysia, Johor Bahru \\ Malaysia \\ Dzurllkanian Bin Daud \\ Department of Real Estate, Faculty of Built Environment and Surveying \\ Universiti Teknologi Malaysia, Johor Bahru \\ Malaysia

\section{Salfarina Binti Samsudin} \\ Department of Real Estate, Faculty of Built Environment and Surveying \\ Universiti Teknologi Malaysia, Johor Bahru \\ Malaysia

\section{Falilat Kadir} \\ Department of Estate Management \\ Federal Polytechnic Offa \\ Nigeria
}

*Corrosponding author's Email: tizainab@graduate.utm.my 


\section{$R_{i}$}

\section{Science Proceedings Series \\ (SPS) \\ www.readersinsight.net/SPS}

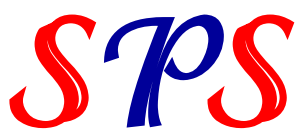

\section{R E S E A R C H H I G H L I G H T S}

Real estate development usually involves a multi-step process that can be complex, long-lasting and uncertain, it generally takes years to bring a development from the early planning phase through construction to final completion and there are profuse of problems that can follow alongside the developers are however the managers of this activities and take the highest risk in the creation or renovation of real estate development. Data was collected amongst 120 property development firm in Abuja through self-administered questionnaire and was analyzed using descriptive statistics. The study revealed that fluctuation in construction cost, rent fall reflecting possible depression in the market and interest rate capital being competitive are the highest risk factors that have the most significant effect on real estate development. It is recommended that the government should assist in the regulation of policy to assist development with financial support to boost the sectors.

Keywords: Development, Real Estate, Risk, Property Developer.

\section{RESEARCH OBJECTIVES}

Risk is the uncertainty of an anticipated rate of yield from an investment (1), the risk is also the combination of all the uncertain factors which will have a collective negative effect on the objectives of the development (2). Real estate development investments constantly deal with risks, subsequently, most of the investment verdicts are prepared regarding the future. Real estate development which forms an aspect of property investment is a process of enhancing the value of the real estate by constructing physical changes and improvements through the application of capital and entrepreneurial skill by a property developer (3). The distinct volatility in the property market and the degree of instability in the economy, demand that reporting risk clearly to reflect the potential variations in development variables (4); which makes real estate development projects to be marked by increasing unpredictability and higher risk. Risk problem is apparently not adequately recognized in the practice as it is presently conducted (4)(5). Risks which have not been identified and managed are undoubtedly unchecked threats to a project's objectives, which in turn may lead to considerable overruns in cost and schedule. For this reason, a systematic approach must be taken to manage risks throughout the development of a project This study is therefore conceived to account and communicate risk in real estate development to shield the property developer investment from the possible risk associated with property development. The apprehension is derived from the recognized understanding that a well-prepared risk appraisal in development will provide better and more shielding of clients from the ravages of volatility.

\section{MATERIALS AND METHODS}

The study adopts the quantitative approach, 120 selected property development firms that operate within Abuja according to the directory of the Real Developers Associates of Nigeria (REDAN). These firms were selected using purposive sampling technique from the firms located in the study area. The study employed a survey method with the use of questionnaires from property development firms adopted as data collection instruments from firms. The questionnaire measured the importance (weight) that each respondent attached to each risk element identified. The data collected via this instrument were analyzed particularly using descriptive statistic with the use of frequency tables, percentage and Mean Item Scores based on point Likert scale because the data required spearman ranking in descending order. 


\section{$R_{i}$}

\section{Science Proceedings Series (SPS) \\ www.readersinsight.net/SPS}

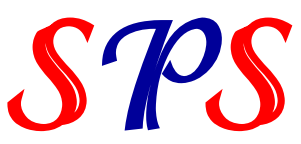

\section{RESULTS}

The impact of risk factors on real estate development variables is estimated to originate by way of a regulated adjustment made of the estimates of project variables besides the lines of a realistic projection of today's estimates of real estate development variables or mildly negative development. Moreover, it is predicted that there would be a need for a higher adjustment of real estate development variables linked with those risk factors that have a high frequency of incidence. There would need to consequently adjust the most significant factor out of the stated risk variables identified

The causes of these can be explained from the macroeconomic consideration, notably from the instability in the country's economy. The economy has experienced a recession and subsequent inflation which lead to unpredictability in costs of imported building materials. These resulted in a balance of payments problem and cash inflexibility, forcing the developer to delay construction work. However, the government has liberalized interest rates on borrowed funds, leading to instability in bank lending rates. The concern that relevant risk factors in real estate development are important because such factors influence the appraisals of development variables with realistic figures in the development appraisal.

\section{FINDINGS}

The necessity to appropriately justify and communicate risk in real estate development to yield a more independent and satisfactory value estimate through the practice of the risk management approach and risk analysis cannot be over highlighted. This is because the better the understanding of risk management, the more risk is abridged in investment. This opportunity would convey appropriate results. However, the study identified that fluctuation in construction cost, rent fall reflecting possible depression in the market and interest rate capital being competitive are the highest risk factors that have the most significant effect on real estate development in the study area

\section{ACKNOWLEDGMENT}

The author will like to thank the Tertiary Education Trust Fund (TETFUND) for their financial support in this research work.

\section{REFERENCES}

1. $\quad$ Baum AE, Crosby N. Property investment appraisal. John Wiley \& Sons; 2014.

2. Khedekar S, Dhawale AW. Qualitative Risk Assessment and Mitigation Measures for Real Estate Projects in Maharashtra. 2015;3(4):49-57.

3. Evans R, Brereton D, Joy J. Risk assessment as a tool to explore sustainable development issues: lessons from the Australian coal industry. Int J Risk Assess Manag. 2007;7(5):607.

4. Ogunba OA. Principles \& Practice of Property Valuation in Nigeria. Atlantis Books; 2013.

5. Otegbulu A., Mohammed MI, Babawale G. Survey on Risk Assessment Techniques Applied in Real Estate Development Project in Nigeria (A. J Contemp Issues Real Estate. 2011;1(1):189202. 